\title{
Eduard Strasburger-dead for a century, but still alive
}

\section{Peter Nick}

Published online: 5 September 2012

(C) Springer-Verlag 2012

\section{Science and tradition}

The decay rate of biological knowledge is estimated to be in the range of less than a decade. In times, where students perceive scientific bibliography as typing a search term into Google, any knowledge not accessible in electronic form is judged to be outdated. Why on earth should we then commemorate a scientist, who died just a century ago? What should we learn from a biology that operated without genes, proteins and the toolkit of molecular biology? Why should we waste our time to read books that needed many years to be written, when we can acquire almost instantaneous access to almost any information we can think of (and even to that not even thought of)? Is it more than nostalgic romanticism to read about the life and thoughts of scientists that, in deprivation of our molecular tools and informational resources, shaped their concepts and ideas, looking through awfully bad microscopes?

The answer is a decisive yes. The biological advance acquired during some millions of years of human evolution is modest - our fur has vaned a bit, and our brain volume increased in compensation. The decisive achievement of mankind was cultural evolution driven by tradition across the borders of genetic relationship. When we continue to reduce the time perspective of scientific tradition to the currently usual one to maximally two decades, we will progressively loose what we have won. Tradition is not a fixed object, but an everlasting flow of learning and teaching, and there is quite a lot we can learn from nineteenth century cell biology - most of the concepts we discuss today had been developed already at that time. Since methodology was far more limited, the focus of scientific work was more conceptual. In these days, where high-throughput

P. Nick $(\bowtie)$

University of Karlsruhe,

Karlsruhe, Germany

e-mail: peter.nick@bio.uka.de approaches flood our brains with answers to questions we never asked, it is a fruitful antidote to return to the realm of questions. If we succeed to integrate the conceptual strength and scientific perseverance of cell biologists like Strasburger and Purkinje with the wealth of current tools and methods, we will be able to develop cell biology to a new level of insight.

So, in the current issue, we decided to slow down the pace of current research and have a look back: It is exactly one century, when Eduard Strasburger died in Bonn, and we commemorate this anniversary by three contributions.

\section{Why should a physiologist need a microscope?}

The scientific genealogy of Strasburger can be traced back to Jan Purkyně/Purkinje whose life and scientific legacy is described by Žarský (2012) in the current issue. He acted as the Founding Father of cellular theory, who not only smoothly integrated different fields of science but also different languages and cultures (being Czech by origin, supporting Polish literature and arts and writing and teaching in Latin and German). When appointed to the chair of physiology in Wrocław/Breslau, Purkinje asked for a new microscope because he decided that physiology had to be traced back to its material and structural base, a thought that was as new as it was alien to most of his contemporaries. After he eventually got his microscope, he not only discovered numerous new cellular structures, for instance in 1825 , the nucleus of an egg cell or the famous Purkinje cells in the cerebellum, but also thoroughly linked structure and function, for instance, when he showed how the peculiar cell wall thickenings in the anther provide a mechanism for pollen dispersal. We should remember that the conceptual base for structure-function relationships was not known at that time-Darwin's book was written decades later.... Purkinje was taking science very seriously, and being trained in nature philosophy, he was always very sensitive 
for the role a researcher plays in the experiment, driving this attitude to even radical and heroic self-experiments in the field of sensory physiology. His scientific impulse became very important for Strasburger: A friend and schoolmate of his two sons, Julius Sachs, encouraged to study plant physiology, developed Purkinje's legacy for the field of plant physiology and later became one of Strasburger's most influential teachers in Bonn.

\section{Towards cell theory}

The scientific path of Strasburger is described in the second contribution by Volkmann et al. (2012) in the current issue. During his study years in Bonn, he was inspired by Julius Sachs' teaching on sensory physiology and the importance of microscopy to investigate the indivisible link between structure and function. He continued his work in Jena, where he was not only imbibed with evolutionary thinking propagated by Ernst Haeckel but had also access to state-ofthe-art microscopy, which allowed him to make fundamental contributions to cell biology, including the structural dynamics of cell division and the relation between nuclear division versus cytokinesis. After his call to Bonn, he basically merged and developed three streams of tradition: comparison of different species to identify commonalities of mechanism (an evolutionary approach stimulated by Ernst Haeckel), ample use of high-quality microscopy to identify the structural base of life (a technical advance, whose power he could experience during his time was close to Ernst Abbe in Jena) and the conviction that structure has to be understood in terms of biological function (the legacy of the Purkyně/Purkinje and Sachs stream of tradition). As all his scientific forefathers, he continued the tradition of highlevel teaching. His textbook, the famous "Strasburger", has now continued for more than a century (the first edition dates from 1894) to summarise our knowledge on plants, and it has continued to convey the idea of functional morphology into the curricula of university biology. This approach has remained fruitful even in the molecular era. No matter whether we deal with cellular structures or with gene products, in order to leave the level of mere description, we need to elucidate functional relationships to reach the level of explanation. Strasburger had inherited Purkinje's approach to challenge even the most beloved scientific concept on the stage of experimental evidence. When he revisited, using improved histology, earlier concepts, for instance, his original idea was that the chromatin is organised as one single thread, and when he found them to be erroneous, he readily admitted his error and explained how it had happened and why he thinks, meanwhile, that the earlier concept was wrong. So, his scientific work developed as a continuous flow rather than as a collection of fixed milestones of knowledge.

\section{Why Strasburger is still alive}

The third contribution, by Baluška (2012) in the current issue, highlights Strasburger's legacy for the development of a contemporary cell theory. It is pointed out how the comparative approach and the choice of appropriate cellular models led to the conclusion that nuclear division and cytokinesis are independent. This comparative approach is then extended over the three kingdoms of life to pinpoint some commonalities that are often overlooked and to describe how Strasburger's emphasis on the genesis of the nucleus merged with the idea of energids, perinuclear areas of influence, which was put forward by Julius Sachs, can be merged into a concept where the nucleus (possibly deriving from an ancient predator) acts as highly autonomous pacemaker by using the perinuclear cytoskeleton that organises "its cell" according to its needs.

What are the lessons from the Strasburger tradition? First, there is no structure without function and no function without structure. Second, there is no scientific progress without strong impact on a conceptual framework. Third, our concepts depend on the technology we have available. The last and most important: when observations conflict with ideas and when we have come to the conclusions that our observations are sound, we have to change our ideas.

\section{Conflict of interest None.}

\section{References}

Baluška F (2012) Strasburger's legacy to mitosis and cytokinesis and its relevance for the cell theory. Protoplasma (in press)

Volkmann D, Baluška F, Menzel D (2012) Eduard Strasburger (1844-1912): founder of modern plant cell biology. Protoplasma (in press)

Žarský V (2012) Jan Evangelista Purkyně/Purkinje (1787-1869) and the establishment of cellular physiology-Wrocław/Breslau as a central European cradle for a new science. Protoplasma (in press) 